\title{
Effects of Violence and Economic Crisis on Hybrid Transnational Partnerships
}

Violence related to the drug trade had moved into the southeastern part of Jalisco when I arrived in August 2009, although I did not know that at the time. When I selected the case of Santa Catarina, I had intended to learn about a case of failure. The migrant club from Santa Catarina that completed the transnational survey reported they were inactive. When I looked more closely at survey responses, the answers to questions about resident involvement in coproduction activities was low and the club reported problems receiving funds on time from the municipal government. When I followed up with club leaders, they told me the remittances the club had deposited in the municipal treasury for their very first coproduction project—a street pavement project—had gone "missing" when the new municipal administration took office six months after they agreed to participate in the 3x1 Program. The club disbanded shortly thereafter.

I was eager to understand whether low levels of community inclusion and government engagement indicative of a fragmented partnership led to failure and the extent to which this failure had observable spillover effects on local political engagement. Conversations with paisanos from Santa Catarina confirmed initial support for the hypothesis that fragmentation left migrant clubs vulnerable to unscrupulous political actors, especially when local residents were uninvolved in coproduction activities and did not provide on-the-ground oversight. What I also learned was that residents were uninvolved in the $3 \mathrm{x} 1$ project because the program required municipal government engagement and residents suspected the administration was either directly or indirectly implicated in drug violence. In the case of fragmented coproduction in Santa Catarina, community inclusion was impacted by both migrant social embeddedness and drug-related violence. 
Increased violence related to the drug trade was a factor that affected the organization of a transnational partnership in Santa Catarina through its negative effects on community inclusion.

In this chapter, I present two intermediary cases of transnational coproduction: synergy in Ahuacatl, Guanajuato, and fragmentation and failure in Santa Catarina, Jalisco. In each case community inclusion was impacted by migrant social embeddedness, but also by additional factors in Mexico and the United States. I contrast hybrid forms of synergetic and fragmented coproduction to show how crises in the place of origin (drug violence) and destination (the U.S. economic recession) can affect the ways in which residents and local government respond to migrant cross-border investment in hometown communities, which shapes their level of participatory engagement in project governance and public life more generally. Drug violence in Santa Catarina deterred community involvement through its effect on both community inclusion and government engagement, while the recession in the U.S. handicapped Club Ahuacatl's capacity to raise collective remittances for their hometown, which necessitated further escalation of community involvement to continue coproduction projects.

The two transnational partnerships produced different political consequences in Ahuacatl and Santa Catarina. In Ahuacatl, more residents became civically engaged in hometown public affairs and developed a new civic association to solve public goods problems with the local government without the financial support of the migrant club when HTA capacity waned as a result of the U.S. economic downturn. During the synergetic period, migrants created vertical links between community leaders in Ahuacatl and the municipal government in the county seat that allowed them to continue coproduction projects directly with the citizens of Ahuacatl with matching funds from the state and federal governments. In Santa Catarina, residents did not become more involved in local public affairs and the failed transnational partnership confirmed their suspicions of municipal corruption. The partnership reinforced the status quo--high levels of distrust in the local political process and low levels of participatory engagement. But in the case of Santa Catarina, the drug trade played an independent role both in the way it discouraged community involvement in club activities in 2006 and, after 2012, when it depressed civic and political engagement even more.

Drug violence and economic crisis in the U.S. are likely to play significant roles in migrant cross-border investment and coproduction of public goods through their intervening effect on community inclusion, government engagement, and club capacity as the cases in this chapter illustrate. This is especially true after 2009 when the U.S. recession severely impacted the labor market in employment sectors that heavily relied on low-wage immigrant labor including services, construction, and agriculture. Migrant clubs that had previously invested collective remittances in hometown projects had difficulty retaining club members and raising funds. Energy, time, and resources of migrant club members and leaders were severely 
taxed during the economic crisis, which strained their capacity to organize, coordinate, and fund public goods projects across national borders.

Additionally, after 2006 Mexican president Felipe Calderón declared war on drug trafficking and the cartels. In migrant hometown settings in Michoacán, Jalisco, Guerrero, Durango, Guanajuato, Estado de Mexico, and other central western states, criminal organizations splintered and new organizations formed, which created competition for territory and revenue in places in which the drug trade was previously less of a concern. In response to the growth of criminal activity in some high migration areas where coproduction was an everyday affair, some HTAs temporarily halted their efforts and adopted a "wait and see" approach. I learned in follow-up interviews with migrant contacts that after 2012, paisanos and municipal officials that participated in the 3x1 Program became targets for extortion by gangs. This was routine practice in parts of Guanajuato by 2012. To coproduce public goods projects, gangs required kickbacks or bribes, which were paid by the municipality and migrant groups. In other locales, some HTAs shifted their support from public infrastructure projects to public security initiatives including armed vigilante militia groups called autodefensas to protect their hometown communities alongside local residents. Still in other cases, I learned from key informants that some HTA members were implicated in criminal activity and had direct links to criminal organizations, with some ties forged voluntarily and others by force. Across Mexican sending communities, drug trafficking and criminal organizations affected 3x1 projects directly and indirectly through their effect on citizen and government participation in coproduction and when organized crime inserted itself into project governance.

A note about the case of Santa Catarina. Unlike in other hometown settings where I conducted fieldwork, residents of Santa Catarina were more closed off. Some residents accepted invitations for informal interviews, while others declined to chat about migration and political life in the town. I did not know before I arrived that residents were fearful that violence that stemmed from cartels had come close to Santa Catarina and they were intent to keep a low profile. Before I arrived, word had begun to spread that migrant families were being threatened, targeted for kidnappings and ransom. Given the public security concerns, I left Santa Catarina before I would have liked. ${ }^{1}$ As a result, the case relied more on interviews with paisanos in the U.S. and fewer key informants in Santa Catarina than in other cases. Some questions I was not able to fully resolve; I note them in the presentation of the case. This case, more than others, is thus skewed toward migrants' perspectives as I was unable to learn from as many locals about how they experienced the coproduction project compared to other cases. Even though the case has limitations, I include it because it helps account for more organizational variation in transnational partnerships and reflects empirical realities in Mexico that migrants and Mexicans have been forced to confront. 


\section{FRAGMENTED COPRODUCTION IN SANTA CATARINA, JALISCO}

Santa Catarina is a rural municipality in the southern region of Jalisco ${ }^{2}$ and one of the poorest municipalities in the state. In 2000 , almost 20 percent of the population over the age of 15 was illiterate and only about a quarter of the population finished primary school. In the five main localities, between 8 and 15 percent of residents lacked access to basic services such as potable water, sewerage, and electricity. The majority of residents raised cattle and other animals including pigs, sheep, and goats and grew sugar cane, sorghum, and beans. While the land was once fertile, severe drought in the late 1980s hurt agricultural production. The macroeconomic crisis in the 1990 s further compounded economic hardships from low crop yields as farmers had not yet recovered from droughts that hampered their crops over the previous five years. To cope with massive economic downturn, many residents of Santa Catarina left for the U.S. By 2005, about a quarter of the working-age population was unemployed and most households had a family member who lived abroad. ${ }^{3}$

High rates of emigration altered society, economy, and politics in the municipality. With few prospects for economic security, the social base of Santa Catarina was dramatically altered as entire families left the municipality for permanent settlement abroad. Over the span of a decade, siblings, spouses, children, and grandparents reunited with family members in Houston, Chicago, Riverside, Los Angeles, and San Jose after several years of separation. Those who stayed behind were primarily spouses and parents of migrants who cared for children and relied on remittances sent home. Most of the other families that remained were too poor to emigrate and felt tied to land passed down to them over generations. They worked as subsistence farmers and sold any surplus crops at the local market. The households that were more economically secure in Santa Catarina were the families affiliated with the cacique (informal system of boss politics) that supported the PRI.

Poverty and unemployment were cause and consequence of migration in the rural municipality of about 5,000 residents. While emigration provided economic security for many families in Santa Catarina, it also meant that the economically productive workforce lived in the U.S. and parts of Santa Catarina were virtual ghost towns. Some residents I spoke to also thought migration made young men in Santa Catarina vulnerable to the drug trade. When teenagers saw how migrant families were able to improve their homes with remittances dollars and could purchase more material goods (clothes, shoes, appliances, and electronics, for example) they wanted to leave for the northern border too. But when they could not afford a coyote (the name given to human smugglers) to help them cross the border and did not see education as a mechanism of social mobility, many were believed to have joined local gangs with ties to larger, more organized cartel 
networks in Jalisco and across the eastern border in Michoacán. A priest of the local Catholic church speculated that when they no longer saw a future in Santa Catarina they became vulnerable to gang recruitment, some soon swept up into the illicit activities of the drug trade and some suffering addiction as well. He recalled a significant turning point came in Santa Catarina in 2010 when the Cártel de Jalisco Nueva Generación took over the region.

Increasing drug violence and criminal activity related to the trade may have played a role in levels of community inclusion in coproduction activities in 2006 and 2007 when the migrant club first sent collective remittances to Santa Catarina. But even before, Santa Catarina did not have high levels of trust and reciprocity in the community, partly attributed to the disruption to the social base of the hometown caused by substantial emigration to the U.S. over the preceding decade. Social life in in the municipality focused almost exclusively on the fiesta patronal activities in May and religious celebrations in December. The only other active civic association residents knew of in the town was the local church group. Some residents said there used to be a baseball team that played a few seasons against nearby municipalities, but other than that, the town was quiet and residents mostly kept to themselves.

Unlike in other municipalities where I was invited to stay in the homes of local residents and migrant families, sometimes at their insistence, some residents in Santa Catarina were more distant. When residents agreed to speak with me, I was invited into the privacy of their homes, in their stores, or I met with them in the church. On its own, this was not unusual-I frequently spent time in the households of residents in other hometown communities. But in those other communities I also sat in people's yards and accompanied them to work and weekly mass, on errands, and family visits. I also frequently joined residents for lunch in the plaza, attended family and community celebrations with them all over town, and walked with them through agricultural fields and on horseback. This occurred less frequently in Santa Catarina. Most residents and the priest spoke to me indoors. Those residents who were open to chatting with me also tried to connect me with their friends and families who were from migrant households. But when these residents reported back to me about possible meetings with other residents, many said they were "unavailable." Instead, they gave me the contact information of their family members in the U.S. and said I should contact relatives abroad who would tell me about life in Santa Catarina. I sought out their relatives in the U.S. and talked with them over the phone and after I returned to Chicago. I began to more fully understand when I spoke to migrant relatives in the U.S. that locals were simply trying to keep a low profile at the time. For many, socializing with the lightskinned American woman in town drew too much attention.

In other migrant hometowns where I conducted fieldwork, locals told me about social and political experiences in the municipality in addition to the migrants involved in hometown clubs and political officials. But for the case of Santa 
Catarina I had to rely more on the secondhand accounts of migrant family members, a few shop owners who did not have any relatives abroad in the town, the local priest, and members of the church group. I never asked anyone about the drug trade while I was in the town. However, some residents volunteered to me that they thought Santa Catarina had become unsafe. They worried about public security and told me stories of locals being kidnapped for ransom. As Yessica, a friend of the priest and wife of a migrant in Riverside, told me, "Nobody trusts anybody around here and you need to look over your shoulder more these days." I learned from local residents how they made the sign of the " $Z$ " on their hands to reference the cartel. The " $Z$ " specifically referred to the cartel Los Zetas, which was rumored to be present in the region as early as 2006 as they expanded their territorial scope.

At the time I conducted my fieldwork, it was not clear to me that migrants knew about locals' concerns about illicit activities and the presence of gangs in and around Santa Catarina. Migrants never mentioned criminal violence or gang activity when I first spoke with club leaders in 2008 , the year after the club became inactive. When I returned to Chicago and told club members about local fears of the drug trade dating back to late 2006 when the club was active, they said they were unaware and did not know of any families that were targeted. It could be that club leaders intentionally kept this information from me or dismissed the information as rumors, although I suspect they really did not know. The priest said he never discussed criminal activity with the migrants at any time because it was not something you talk about openly in Santa Catarina.

Migration also tangentially impacted local politics. The PRI maintained firm control of the municipal government and won most elections by double digits against a weak PAN opposition with the protracted support of a cacique. Before the elections in the summer of 2010, no opposition political party had won the municipal presidency. A few residents who were part of the church group believed that migration contributed to the PRI's support. As more residents left for the U.S., they said, the more people became disinterested in politics. Residents believed that people who left for the U.S. were those who cared about politics and people who remained behind were either those who were ardent Priistas and connected to the cacique or poor and unlikely to participate in public life beyond attendance at the annual fiestas. According to official government elections statistics, on average, about half of the voting-age population in Santa Catarina turned out to vote in the previous three elections.

\section{CLUB SANTA CATARINA AND THE FRAGMENTATION OF HOMETOWN SOCIAL TIES}

In 2005, five friends living in Chicago (Aurora and Bolingbrook, Illinois) traveled home and attended the fiestas guadalupas held in Santa Catarina in early 
December. During their two-week visit the priest of the Catholic church approached the migrants and asked them if they would help finance a new church roof. The historic church was in disrepair and the priest was unable to raise the money needed for the roof on his own. The migrants knew many paisanos from Santa Catarina in the Chicago area and agreed to collect funds, mostly knocking on doors and taking a collection at church events in Aurora and Bolingbrook where many paisanos lived. The paisanos collected over $\$ 1,000$ over the span of a few weekends from about 100 families that lived in the Chicago metro area. Miguel and Raul, two of the paisanos who visited their hometown during the festival and helped collect donations, never thought of themselves as a hometown club at the time. In fact, they organized to help raise money for the church project and thought that would be it.

Raul and Miguel were some of the few migrants who had returned for visits to Santa Catarina since departure. It was not as common in Santa Catarina as it had been in other communities I visited for migrants to return for visits and for longer stretches during the Christmas holiday season. But Raul and Miguel, unlike many of the paisanos from Santa Catarina, had secured green cards, which allowed them to traverse the U.S.-Mexican border with greater ease than undocumented paisanos. Raul married a Mexican woman from Jalisco in the 1990 s who had naturalized, which granted Raul the opportunity to apply for a green card after they wed. Miguel's mother brought 12-year-old Miguel and his younger siblings to the U.S. in 1980 and rejoined their father who had found stable work in Aurora. Once he turned 18 and obtained his green card through provisions passed in IRCA, Miguel visited Santa Catarina a few times to see uncles who remained behind and worked the family's agricultural land.

Other than a few distant relatives and a few family friends who never migrated that the men kept in touch with on social media, Raul and Miguel did not have many social contacts left in the hometown. They still had houses in the town, but the houses sat empty. Most of their close friends and family had joined them in the U.S. over the last 10 years. They did not know members of the church association personally and wired the donation money directly to the pastor, who coordinated the collection of materials and hired the labor for the job. The migrants only saw the completed church roof when they returned for the annual patron saint festival in May 2007.

The paisano-financed project efforts scaled up when the priest learned about the $3 \times 1$ Program from a pastor of another church nearby. A friend told him about the hometown club in his town that partnered with the municipal government on several public works projects. The priest hoped that the paisanos who had helped him with the church could be persuaded to propose projects through the $3 \mathrm{x} 1$ Program and scale up their efforts. Over the phone, the priest encouraged Miguel and Raul to read about the 3x1 Program online and to ask about it at the Mexican consulate in Chicago and to their paisano friends from other municipalities in 
Jalisco. Miguel and Raul asked a few paisano friends about the program and found out many Jalisciences in the U.S. were also members of a migrant club that completed projects through the 3x1 Program. Once they heard about other successful migrant clubs and the completion of projects through the program, Miguel and Raul said they would be interested in doing more projects, but they had serious reservations about working with the municipal government.

The paisanos wanted to do more projects for the town, but they were wary of proposing projects to the municipal government and did not like going to the Mexican consulate. Miguel said, "We can't raise the kind of money that would have a bigger impact in the town by knocking on doors in Illinois. We needed the help of the government to do more ambitious projects."4 But neither local residents nor the paisanos from Santa Catarina had many favorable things to say about political officials in the municipality and on several occasions the migrants had been treated poorly by Mexican government officials at the consulate. They were reticent to formally propose a project through the $3 \times 1$ Program if it required "dealing with the government," Raul said. Moreover, they heard about the $3 \times 1$ Program secondhand and only had a cursory understanding of how the program worked and the process by which coproduction projects were implemented in municipalities.

The final decision to participate in the program was made with the support of the large network of Santa Catarina paisanos with whom Miguel and Raul had become acquainted during the collections for the church roof. Since the men were still wary about the $3 \times 1$ Program, they decided to have a meeting with other paisanos and get a sense of how interested other people were in doing projects with the Mexican government. The reluctant club leaders did not want to do it alone. At the meeting, the paisanos in attendance (about 20) decided to officially form a migrant club. Over dinner and drinks, they decided to pave the four main streets in town, which they saw were crumbling and badly in need of repair during their previous visit home.

Despite collective reservations about working with municipal officials, they said they felt reassured participating in the 3x1 Program because the state and federal governments were also involved in matching funds. The paisanos thought the involvement of higher tiers of government in the program was intended to inject more oversight into the coproduction process. The migrants did not understand that the $3 \times 1$ Program required matching contributions from the state and local governments, with the rest of project coordination falling to the migrants and the municipal government. Miguel recalled, "We didn't want to interact with any kind of government official. You have to understand that they have treated paisanos badly in the past and we often get harassed at the border." Despite their reservations, they forged ahead and agreed to ask the mayor to work with them on the project at the fiesta patronal in May 2007. The priest helped them organize a 
meeting with the mayor's administration upon their return. In the meantime, paisanos from the newly formed Club Santa Catarina fundraised through potlucks, picnics, and by soliciting donations door-to-door as they had done for the church roof project, and they registered their club with the Institute for Migrants Abroad.

\section{BEGINNING AND ENDING OF THE TRANSNATIONAL PARTNERSHIP WITH THE MUNICIPAL GOVERNMENT}

At the outset, it appeared that local government officials were interested in coproduction projects with the migrant club, and migrants were cautiously optimistic that they would complete the pavement project. In the meeting, the migrants explained what they knew about the $3 \times 1$ Program to the mayor as he said he had not heard of the matching grants schema. The PRI mayor agreed to work with the migrants on the pavement project the club had selected. From that point, the mayor said he and his staff would finalize the budget estimates for the project and send it via email to Miguel and Raul in Chicago for final approval.

The paisanos returned to the U.S. hopeful about the project and told the other paisanos about the mayor's support of their pavement idea. The social development director of Santa Catarina sent the $\$ 3,000$ project proposal. They had already raised their $\$ 3,000$ contribution and wired the money to the municipal treasury while they waited for final approval from the 3x1 Program. Once approved, the migrants, back in Chicago, waited to hear about how the project progressed. That is when the worry set in. Raul and Miguel began to second-guess themselves. Raul explained:

We had a lot of momentum going into the pavement project. I asked some residents what they thought of the street pavement idea at the fiesta patronal . . . they seemed in support of it. Officials put together the budget proposal and we put the money into the municipal treasury so we thought everything was going good, but we were in Chicago, we really didn't know what was happening. And then we waited and waited and waited. Nothing happened. We called the mayor's office and they never returned our calls. Our paisanos called some families to check on progress on the project, but nothing was happening and no one wanted to go ... ask what was going on. We called the state $3 \times 1$ official, but nobody had any answers for us and told us to call a bunch of other people. ${ }^{5}$

For months, the migrants waited and called the director of social development in the municipality to no avail. Work commitments did not allow Miguel or Raul to visit Santa Catarina to have face-to-face conversations with the municipal administration. After several failed attempts to follow up with local officials, a new mayor was elected (PRI) and prepared to take office. The club's $\$ 3,000$ contribution to the proposed pavement project vanished. "No one would tell us anything," Miguel said. "We lost all the money and had to tell our paisanos that we lost the money." 
Any hope Club Santa Catarina had to complete more projects with the municipal government vanished along with the money.

\section{LACK OF MIGRANT SOCIAL EMBEDDEDNESS AND COMMUNITY INCLUSION}

Thirty years in the U.S. had depleted Miguel and Raul's social ties to people who remained in Santa Catarina, and as a result community inclusion was low during the pavement project. It was low because neither migrant had a strong bonding network back in the hometown nor did they have bridging ties to anyone other than the local priest who helped them form the club. At the fiesta patronal, Miguel and Raul reconnected with school friends and cousins from before they migrated. The club leaders said they had a wonderful week and caught up with people whom they had not seen in many years. Even though both men had green cards, between the two of them they had only been back to visit Santa Catarina four or five times since their migration. Furthermore, much of their social connection to the town was only to distant family that remained behind-most of their close family and friends had migrated at some point between the 1990 s and early 20oos. The breadth and depth of migrant club leaders' social ties had shifted over time from the hometown to the paisanaje network in greater Chicago that comprised more and more of their bonding social network.

Some residents who knew about the paisanos' plans to participate in public goods provision in the hometown were ambivalent, while others did not know anything about the migrant club or the proposed project. When I asked residents in Santa Catarina if they wanted to be involved in the pavement project, some said they thought the migrants were "crazy to work with the government" and "why do they still care about the roads [here]?" Other residents confirmed that they had met the paisanos and shared casual chit-chat about people they knew in common in Chicago, but that migrants did not formally try to recruit anyone into the project process. A member of the church group, Lila, expressed what many people told me during my visit. She said it was "fine if people want to donate whatever they can, but we were only focused on church activities like cooking for the poor." Residents did not see a role for themselves in public goods provision and were agnostic about the migrant club's involvement. It was not that residents did not care about the provision of public works. When I asked them what kinds of public works projects they needed in their town, everyone had opinions about what kinds of project would improve their quality of life, namely public security and better roads. But residents reported they were not recruited to participate in the project by the migrants nor did those who knew about the project proposal approach the migrants about becoming more involved.

Miguel reported that he wanted people to believe in the club and help them with the project, but he got the impression during his visit that people "did not really 
seem to care." In the case of Santa Catarina, even if the migrants had been more socially embedded into the hometown community it would likely have taken more than one project to get more people involved in cross-border public goods provision. Not only did migrants not know many people who still lived in town, their only visit was usually during the week of the patron saint festival. It would have been difficult to build bridging ties in a place with deep-seated mistrust of the local government. The social and political obstacles to successful coproduction were overwhelming in the case of initial transnational coproduction in Santa Catarina.

Club Santa Catarina disbanded after the failed attempt to coproduce a pavement project with the local government through the 3x1 Program. Local residents I spoke to said they had little trust in elected officials before the failed pavement project and their suspicions were confirmed after rumors spread throughout town about the "missing" or "stolen" resources. Conversations with church members, business owners, family members of migrants, and a schoolteacher suggested efforts to coproduce public works with the municipal government confirmed what residents already suspected: the local government was corrupt. But the exposure of wrongdoing by the PRI exacerbated distrust in the local democratic process. "Look, you see why I told them they were crazy to give authorities their money," a shop owner said when I asked him about his reaction to the news the paisano funds went unaccounted for. Residents had always suspected political officials were involved in outright corruption and cronyism, but some said that the failed 3X1 project gave them "proof."

Club Santa Catarina did not muster the support of community residents in the coproduction process and local government engagement was low. The local PRI government shirked their 3X1 matching responsibilities before the state and federal governments even deposited their contributions to the pavement project in the local treasury. With the interruption of the municipal election in the midst of the project, officials in the new mayor's administration said an "accounting error" occurred during the transition in power. I neither pressed my contacts in the municipal government for more information nor spoke with members of the cacique. Local residents discouraged me from questioning the elite families in town who were associated with the cacique out of concerns for my security.

In municipal history, no opposition party had successfully defeated the PRI for the mayorship in Santa Catarina. Even though Miguel and Raul were liked by some residents, they could not get residents interested in the 3X1 project, although there is little evidence that they tried very hard to recruit them into the process and residents seemed satisfied to have the migrant club complete projects without their involvement. Even the priest who introduced the paisanos to the program, set up the meeting with the PRI administration, and completed the church roof project with paisano donations did not want to take on any kind of leadership role in the pavement project when the municipal government was formally involved through the 3x1 Program. 
Miguel and Raul expressed interest in doing projects in the future but did not believe they could raise money from the paisanos after the original contributions disappeared. Some paisanos refused to work with the PRI after what happened. Upon further reflection, paisanos said they were "naive" (ingenuo) and "should have trusted their instincts." I asked the priest about the prospect of future projects and he also expressed reluctance given rising public security concerns:

Paisanos work really hard in the U.S. It's a sacrifice for them and for their families. And our residents here work hard too. I don't blame our residents for not wanting to get involved in projects when officials are supposed to do it. We are a poor community. We have to do a lot for ourselves without help from anyone... and since the situation has worsened (referring to the drug trade), no one wants to bring any attention. Everyone tries to keep a low profile these days. ${ }^{6}$

The club became inactive in 2007. While Miguel and Raul still felt a strong connection to Santa Catarina, they no longer expressed those affective ties through cross-border investments in the hometown any more. Rather, in their expansive paisano network in Chicago, they continued to participate in social events with other paisanos and replicated cultural repertoires rooted in hometown social life, but in the U.S.

\section{POLITICAL CHALLENGE FROM AN UNLIKELY \\ ALLIANCE AND A NEW TRANSNATIONAL \\ PARTNERSHIP}

The PRI remained in office until a contentious election in 2010 that ended in the surprise victory of an unlikely candidate. The PAN and PRD, major opposition parties, formed an alliance and ran a mayoral candidate on a public security platform, promising to tackle the rise in drug-related violence in the area. This was a bold move as other mayors or mayoral candidates who openly challenged and confronted gangs became targets themselves, especially across the border in Michoacán in which there were both informal and formal accounts of threats to political authorities. In many cases, municipal authorities had to pay "fees" (cuotas) to criminal organizations to conduct the everyday business of local government. In extreme cases, authorities who did not comply or challenged criminal gangs were murdered.

While details of what ultimately led to the ousting of the PRI were still unclear after the close election, for the first time in municipal history, the PRI had lost. The alliance victory was momentous. I was not in Santa Catarina in 2010 and paisanos I spoke with only had theories about how the PRD-PAN alliance candidate had managed to defeat the cacique and the local PRI. One theory was that the PANPRD candidate was funded by the Cártel de Jalisco Nueva Generación, which had formed earlier in the year and was quickly gaining ground in the region. Another 
theory was the PAN-PRD candidate had been extorted by local gangs and he paid them what they asked. Paisanos said they "heard from locals" that the gangs would leave Santa Catarina alone as long as he paid what they demanded. The most popular explanation, though, was that the political boss became a target of the drug cartel himself and he was no longer in as much a position of power and authority in Santa Catarina. Most of the theories about the PRI defeat were related, in some way, to the presence of the drug trafficking and organized criminal activity in the region and its effect on local politics.

After the PRI was defeated in 2010, a different group of paisanos from Santa Catarina formed a hometown association in 2011, despite continued concerns related to drug violence. When I spoke with the club leaders in 2011 in Chicago, Club Unido had already completed two coproduction projects through the $3 \mathrm{x} 1$ Program. With matching funds from the state and federal governments they successfully coproduced public lighting (street lamps) along a bridge and purchased an electrocardiogram machine for a local health clinic. Martín and Alejandra, a married couple who emigrated from Santa Catarina in the early 2000 s and formed the new HTA, were not affiliated with Club Santa Catarina in any formal way, but they did donate to the church project. This gave them the idea to form a club of their own when the time was right. When the PRI lost the election, they thought this was a good time and they approached the newly elected mayor about 3x1 Program participation. They heard from some of their friends and family in Santa Catarina that locals thought highly of the new mayor, but they were still careful in how they did business with the municipal administration. They learned from the experiences of Club Santa Catarina:

We don't put any money in the treasury. We do everything in a separate bank account. The new mayor is much better. He's an engineer and has good ideas for the town, but he has a lot of work to do trying to get security under control. It will take a long time for us to gain the trust of local residents who have seen a lot of things happen in this town. We ask them what kinds of projects they want and they tell us, but they won't donate funds or help very much ... We have to work very hard to stay on good terms with the administration and communicate often through video chats and phone calls. ${ }^{8}$

Raul wished the new club the best of luck in their development projects with the new mayor, but former members of Club Santa Catarina were skeptical of the 3X1 process and the lack of accountability. By 2010, drug violence was a well-known secret in Santa Catarina and some paisanos did not want to send collective remittances back to the town because they feared that such public displays of migrant resources put themselves and locals in harm's way. As Ricardo, a paisano from Santa Catarina in Aurora, told me over the phone, "You just don't know who is who and whether doing projects and showing you have money puts a target on your back." Ricardo was surprised Club Unido had completed any projects at all and hoped the "Lord protected them." 
In the case of Club Santa Catarina and their fragmented partnership with local residents and the local government, the municipal administration took advantage of migrants' physical distance and the migrants' contributions to the pavement project budget disappeared. Without more participation from local residents, the migrant HTA in Chicago was unable to exert any pressure on the officials to meet their obligations ${ }^{9}$ and their location in the U.S. prevented them from holding local officials to account for their 3X1 contributions. Moreover, 3X1 officials lamented that they had no recourse to monitor local officials in these kinds of situations. Jaime Almaraz, a 3x1 state-level official in Jalisco and former mayor of Tuxcacuesco, Jalisco, explained to me that in situations like these in which outright corruption occurs, which he said in his experience was more rare, higher tiers of government will sometimes reimburse the club. This has happened only a few times in his recollection. Paisanos in Club Santa Catarina did not approach representatives of Sedesol for a reimbursement because they said they were done "dealing with the Mexican government. All of it." ${ }^{\circ}$ The experience depleted this group of paisanos' energy and interest in cross-border investment.

The fragmented partnership in Santa Catarina was characterized by low community inclusion and government engagement. Fragmented, weak organization between paisanos, residents, and municipal government produced a context ripe for organizational corruption in Santa Catarina. This is not always what transpires from fragmentation, but it is a likely outcome. Citizens were reluctant to engage in the coproduction process and their suspicions were confirmed when the $3 \mathrm{x} 1$ Program resources disappeared. Without support from residents in the coproduction process, Club Santa Catarina was vulnerable. Local government officials were in a favorable position to take advantage of HTAs and their resources for their own benefit or at the behest of unscrupulous local actors involved in criminal organizations.

Corrupt, rent-seeking behaviors take many forms in the coproduction context. Public and private agents may shirk financial responsibilities and inflate project costs to extract additional resources from migrant, state, and federal partners. Political officials, local residents, and migrants collude with preferred contractors and construction companies for kickbacks and change technical plans and costs during implementation for mutual gain. Municipal government may also fail to monitor projects during implementation, which leads to poor quality or lack of project completion altogether. Although I did not witness this in any of the cases I studied for this book, I have heard from informants that in some cases migrants have colluded with governments, not simply to impose their view of what is good for the public, but to use public resources to further their own private ends. Informants' anecdotal accounts often describe some HTAs as "mano negra." the case of Santa Catarina, municipal government officials appropriated the monetary resources contributed by migrant groups. Local government officials were in a favorable position to capitalize on information asymmetries because members 
of the migrant club lived abroad. Without support from local resident citizens, the migrant club had limited mechanisms to monitor political officials' behavior when they were in the U.S. Fragmented partnerships characterized by limited government and resident engagement often fizzle out and fail.

The fragmented partnership revealed to the citizenry the PRI mayor's misdeeds in office. Citizens of Santa Catarina were already disillusioned with the local political process prior to coproduction; this experience compounded their disillusionment. But while political engagement was depressed in the wake of the failed $3 \times 1$ project, more citizens turned out to vote in the 2010 election than in the three previous elections. While other factors were certainly at play in citizens' decision to put their support behind the opposition candidate in 2010, paisanos thought, perhaps giving themselves too much credit, that their failed partnership had exposed government wrongdoing and citizens had punished the PRI in the next election. In the 2010 election, there was an 8 percent increase in turnout among the voting-age population compared to the previous election. Additionally, the PRI's vote share declined 5 percent as citizens shifted their support to the opposition candidate of the alliance party. It is not clear if the failure of the transnational partnership played any part in local participation. In 2009 when I visited the town, public activities, especially those that displayed income, were kept to a minimum and citizens I spoke with said they had no interest in any sphere of participatory engagement with the local government.

\section{SYNERGETIC COPRODUCTION THROUGH THE ECONOMIC CRISIS IN AHUACATL, GUANAJUATO}

Uninterested in school, Juan left his hometown of Ahuacatl, Guanajuato, in his early twenties with six years of primary education. He left for the U.S. in pursuit of his version of the American dream-find work, raise a family, and return to Ahuacatl with enough savings to build a house of his own and care for his aging parents. Finding work in the locality of Ahuacatl or the municipal county seat of Corporeo where Ahuacatl was located was difficult. With no education and no prospects for decent work, Juan had gotten into some trouble with alcohol and decided to leave for the U.S. with the hope of a fresh start. Not many residents of Ahuacatl had emigrated when Juan made the decision to go, although many citizens of Corporeo had left for the northern border and many Ahuacatlenses left later on in the late 1990s. In his town, he was a pioneer of sorts. He saw migrants from nearby municipalities leave and then return with new trucks and remittance dollars, which they used to fix up houses and start businesses. Juan wanted a chance at the same fortune. His parents were subsistence farmers, barely able to provide for their 11 children on the parcel of ejido land the family inherited from Juan's grandparents. Juan was the first of his siblings to leave for the U.S. and made the perilous journey with a coyote alone. Six of Juan's siblings eventually left for the 
U.S. while four sisters and a brother remained in and around Ahuacatl to work the land with their parents.

Most residents, like Juan's family, farmed former ejido land, worked in the bottling plant of a popular Mexican beer company in a nearby municipality, or owned small shops and food stalls in Corporeo. Other residents of Ahuacatl traveled longer distances and worked in more economically active cities such as Irapuato, Celaya, or Leon. High levels of poverty and little attention from the municipal government meant that people had to rely on each other to solve local problems and find employment to support their families.

Despite its larger population than other localities in Corporeo, Ahuacatl was a rather tight-knit community and had a vibrant civil society before the arrival of the migrant hometown club. After a flood rattled the locality in a particularly rainy season, residents came together and collected donations across Corporeo for those who had lost possessions. In the town there was both a popular church organization that regularly met and an active and dedicated Patronato festival group. Additionally, residents had a favorable opinion of the local delegate who represented Ahuacatl to municipal authorities. Some residents affectionately called the delegate El Guaje. ${ }^{12}$

\section{FORMATION OF CLUB AHUACATL AND THE \\ CHALLENGE OF WEAK CAPACITY IN THE U.S.}

Juan's journey to the U.S. was not an easy one. His first trip across the border was unsuccessful and it took a few more attempts before he crossed into Texas on foot. His arrival in the U.S. was jarring. He knew not a soul and work was harder to find that he thought it would be. When times were really tough he knocked on doors and asked strangers for odd jobs. He lived in five U.S. states before he settled in San Diego, California, with his wife, Yesenia. Juan thought himself the luckiest man in the world to have found Yesenia, a Mexican woman of Nahua decent from San Luis Potosí, for he was lonely during those first 10 years in the U.S. On several occasions he was tempted to return to Ahuacatl with nothing to show for his migration. His luck changed when Juan was hired as a security guard and custodian at a private Jewish day school. Juan told me that some students and teachers joked that he was "half Catholic and half Jewish" because of his dedication to the school. By the time I came to know Juan, he had worked at the school for ten years. It was clear that the students cared about him as they practiced their Spanish with him and asked to hear about Ahuacatl and what life was life in Mexico when they saw him in the school hallways.

Once he became more settled in San Diego, Juan visited his hometown more regularly. He visited for long weekends, for a month over the summer break, and for three weeks in December. Juan was a regular figure in Ahuacatl and remained very close to his family and childhood friends. Juan became more accustomed 
to life in the U.S., but he never felt truly at home. He was more comfortable in Ahuacatl, near his horses, on the land, and surrounded by people who shared the same small-town values.

Unlike the migrant clubs in El Cerrito and Telepi that came together on their own, Club Ahuacatl formed at the request of local residents in 2005 and was the first hometown association in the municipality of Corporeo. After Ahuacatlenses heard about a migrant club from the nearby municipality of Acambaro that had finished several public works projects by working with the municipal administration, residents hoped paisanos including Juan who had left in the 1990s would use their social mobility to support projects for the people in Ahuacatl. Leaders in Ahuacatl asked the paisanos who returned for the annual patron saint festival to partner with them and the local government to improve living conditions in Ahuacatl through cross-border collective action.

The patron saint festival was a celebratory time in Ahuacatl when migrants trekked back to Guanajuato from all over the U.S. During the July festival, residents asked Juan, Martin, and Ramon, migrants in town for the event, to form a club and request funds from the municipal government for public works projects. El Guaje knew the paisanos families well and had a friendly relationship with Juan especially, who was a frequent visitor. While paisanos and townspeople gathered together to enjoy música de banda, fireworks, street food, horse races, and the religious festival of candles at the historic Catholic church, El Guaje and the leader of the local church group pulled the paisanos aside and told them about their wish to have a migrant club that helped the town, like the club they heard about in Acambaro.

The paisanos liked the idea, but they had not the first clue about how to run a club or get other paisanos in the U.S. involved. The paisanos were a bit reluctant. El Guaje, a charismatic and charming leader, reassured the migrants that they could start small; "No pressure," El Guaje told them, "it will be fun." By the end of the festival week as the migrants prepared to return to the U.S., El Guaje and the church group met with the paisanos to decide next steps for the new migrant club. The migrants agreed to fundraise in the U.S. for their first official project, which was a common area in front of the church for festivals and other social events. They also decided together that it would be a good idea to install bathrooms for patrons to use in the plaza area.

El Guaje had a plan to raise the project with the municipal administration during their next meeting with the delegados and gauge their level of support. Local elites, namely the doctor and the dentist who lived in Ahuacatl, had strategized with El Guaje that municipal officials might be more inclined to support residents' preferred projects if they brought the paisanos into the picture. Other residents, though, were wary of bringing the municipal government into the partnership with the migrants given the history of the soured public-private partnerships that occurred during President Salinas's National Solidarity Program (Pronasol) in Corporeo. 
The eagerness of residents to work directly with the local government waned after a failed attempt at a public-private partnership for public works provision through the National Pronasol in the 1990s. Citizens in Ahuacatl told me how the resources they contributed to collaborative projects "went missing," "projects were never finished," and the people of Corporeo "no longer had confidence or really trust the municipal government." But El Guaje and other locals thought that if the paisanos proposed projects through the 3x1 Program, the additional oversight from the state and federal governments would ease the concerns of anxious Ahuacatl residents. Ahuacatl elites, who knew the mayor's family well since his wife was from Ahuacatl, thought he was different than previous administrations and would be less opportunistic with the locals and the migrant club. The mayor's social connection to Ahuacatl gave them some reassurances that he would not risk his local reputation.

\section{ROLE OF THE STATE AND MUNICIPAL GOVERNMENTS IN THE TRANSNATIONAL PARTNERSHIP}

Corporeo municipality is located in the southeastern region of Guanajuato near Selvillo. It is a middle-income municipality of about 60,000 residents. Up until 1986, the PRI maintained firm control of the municipality. But since the PAN opposition party wrested the mayorship from the PRI, the two parties have alternated power in the last eight electoral cycles. Municipal elections were hotly contested in Corporeo and Ahuacatl was considered a swing community because voters vacillated in their support for the PAN and PRI. As Oliver, a restaurant owner, said, "In Ahuacatl, we don't vote for the party, we vote for the person." The previous, current, and incoming mayors of both political parties repeated the sentiment. It was well known that during elections, the political parties worked hard for the votes of Ahuacatl and campaigned heavily in one of the most populated localities of Corporeo.

The year 2005 was the PAN mayor of Corporeo, Beto's, second year in office. When El Guaje raised the church project proposal with Beto's administration, he was not initially enthusiastic about the project, which was more social in nature and would do little to improve development goals in Ahuacatl. However, this initial meeting did reveal that he was eager to partner with the migrants on other public works projects that focused more on public infrastructure. Beto had recently heard about the 3x1 Program from another PAN mayor and knew previous PAN administrations had tried, without success, to get paisanos to form clubs and coordinate public goods provision with them using collective remittances. Beto asked to meet with Juan and El Guaje during his return visit to Ahuacatl. In the meeting, they all agreed to first work on the church project through the 3x1 Program, but then they would also collaborate on a drainage project, an essential service that was underprovided in many neighborhoods in Ahuacatl, and a problem that 
often wreaked havoc on the town during the rainy season when floods were more common. El Guaje urged the mayor in the meeting to reassure the residents of Ahuacatl that he would keep his word to support the church program and then move on to other coproduction projects. Beto was a young and enthusiastic mayor with aspirations to move up the party ladder and so he agreed to meet directly with the residents of Ahuacatl.

A few Ahuacatl residents were invited to the Corporeo ayuntamiento along with El Guaje. In the meeting, Beto reassured the citizens that they and the paisanos would stay in control of the projects and the municipality would serve in a supportive role. Beto said that he told them, "The people here in Ahuacatl trust the paisanos more. They have a kinship and connection with them and believe them more than us. We respect that." Residents also trusted Juan, leader of the migrant club, and believed he and El Guaje would serve as a conduit to the administration that represented the town's interests.

When I asked residents why they had so much confidence in Juan, many residents said they felt reassured because he had so much family in Ahuacatl and visited frequently. Since he came back often during the year and stayed for much of the summer, worked on his house and on his family's land with his kids, to some residents like Cindy, it hardly seemed like he had left at all. El Guaje and the town elites' plan-to coordinate public goods provision between the migrants and the municipal government while maintaining a clear voice in the process-worked. Mayor Beto, the director of social development, and the director of public works recognized and publicly addressed the residual mistrust between citizens and the local government. When public officials acknowledged past misdeeds of Panista mayors, the new guard of the PAN was able to extend an olive branch to the citizen voters of Ahuacatl. This effort was strategic by the savvy politicians because Ahuacatl was a swing district that had been known to make or break an election for the PAN. Political competition in Corporeo created incentives for the PAN administration to seek an edge over the PRI opposition through the provision of public goods.

At the meeting, in the presence of the residents, Beto instructed his staff to draw up technical plans, hire contractors, and source the necessary materials for the church patio. Once they received approval from the 3x1 validation committee, the project was completed in a few short weeks. Paisanos, El Guaje, and residents of Ahuacatl were proud of the project and the plaza quickly became a popular place for residents to congregate. El Guaje recalled:

Before the paisano club and 3x1 we tried to organize and do projects for Ahuacatl, but the municipality was difficult to work with. The mayors say they will help but never do anything or it takes a really long time. But with the migrant club the government doesn't take as long to reply, we get a lot more attention from the municipal center. I think it's because they know they can get funds from the state and federal government. 


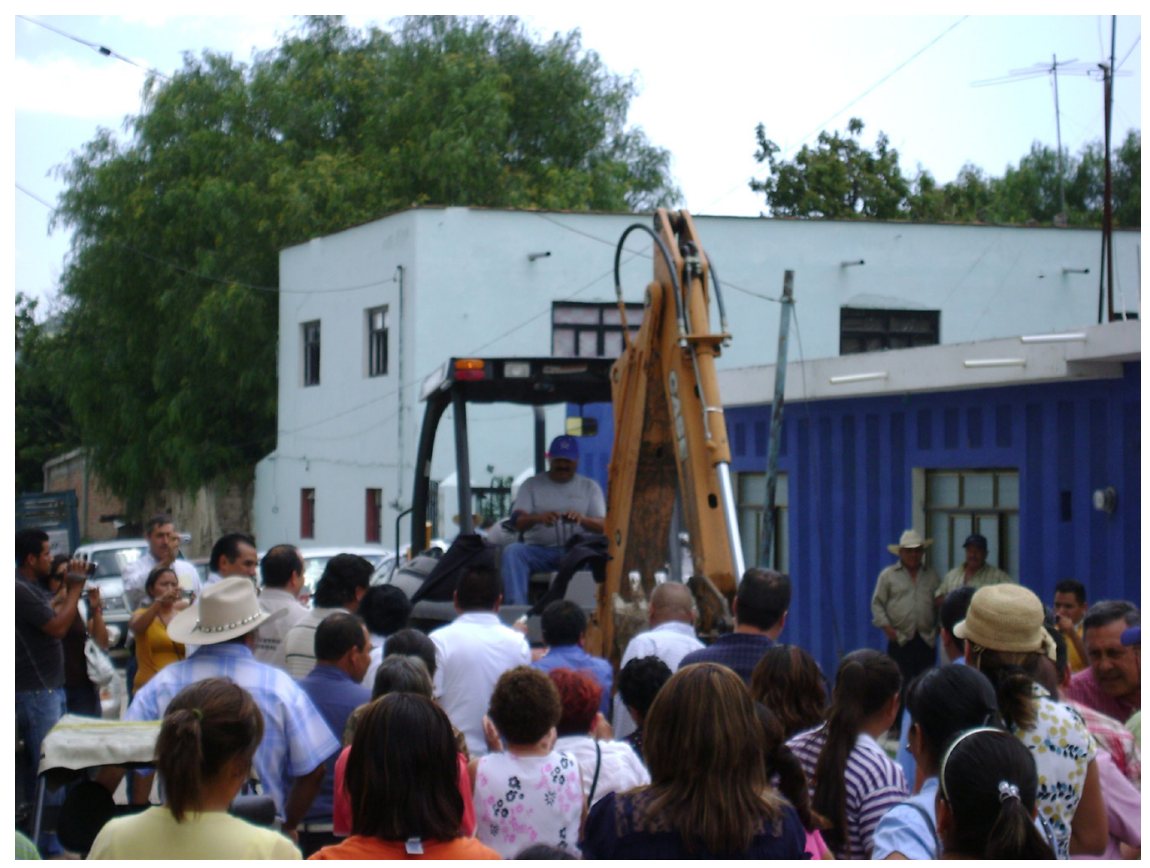

FIGURE 3. Pavement project groundbreaking ceremony with mayor of Ahuacatl. Photo by author.

Residents were still wary, but hopeful the migrants would spur more financial support for public works in Ahuacatl.

On the U.S. side, the club encountered many hurdles. State public officials from Guanajuato affiliated with the Casas Guanajuato program ${ }^{13}$ and the Mexican consulate proved an important resource for the struggling, nascent club. Juan, Ramon, and Martin had a few friends from Ahuacatl in the U.S., but paisanos were scattered all across California and Texas. The three migrants had strong bonding ties in Ahuacatl, but they did not know each other well, and their social connections to other Ahuacatl paisanos in the U.S. were even more limited. The club leaders had family who had migrated, but their social circles were not based on immigrants from their hometown in their places of settlement in the U.S. In Texas, Martin reached out to other paisanos from Ahuacatl with contact information he received from their families. Juan and Ramon reached out to paisanos in the same way in San Diego and Los Angeles. The three men conducted most of their club business over the phone and each collected donations for the project by knocking on the doors of other paisanos, most of them cold calls to strangers who shared a connection to Ahuacatl, but not to the migrant club leaders themselves.

The paisanos' weak social ties to one another and lack of ties to other paisanos from Ahuacatl and Corporeo were challenges for the migrant club. They wanted 
to help the residents of Ahuacatl with projects, but they were inexperienced in leading a club and fundraising. Juan, in particular, thought fundraising was awkward and he did not enjoy it. At this point, he thought the club might be able to raise the money for the church project, but then the club would disband. "It was going to be too hard to keep knocking on doors. And I'm kind of shy. I didn't feel comfortable asking people for money back then. I thought, okay, we'll do the one project that the residents want us to do and that will be it. It was taking a lot of time too," he said. Martin and Ramon had difficulty drumming up support from Ahuacatlenses in the U.S. Ramon said, "It was hard to get anyone on the phone and when we did, they didn't want to get involved in the club or donate resources." Seeing Martin frustrated, his Guanajuatense friends in Texas recommended he visit the Casa Guanajuato in Dallas and see if they could help his club get off the ground.

State officials in Texas and California became a key source of information about the 3x1 Program and the supply of contact information to paisanos from the hometown in the U.S. Personnel at the Casa Guanajuato in Dallas encouraged Martin to get his club registered at a Mexican consulate so that they could formally propose the $3 \mathrm{x} 1$ project to the validation committee at the next meeting in Guanajuato. They also encouraged him to contact the state Migrant Affairs Offices in Guanajuato, which would be able to help them locate other paisanos from Corporeo. With guidance from the Casa Guanajuato and Guanajuato state officials, Club Ahuacatl expanded their network of paisanos from Corporeo in the U.S. and got their club officially registered with the Institute for Mexicans Abroad at the Mexican consulate.

The state government of Guanajuato was a major gateway for the survival and expansion of Club Ahuacatl. Members of the Casa Guanajuato in Texas invited Beto to Texas and set up meetings with other paisanos from the three major localities of Corporeo. The initial visit was successful. Three additional groups of migrants agreed to form clubs and work with Beto's administration on development projects in their respective hometowns. While previous mayors of Corporeo had encouraged paisanos to support development projects in their hometown with collective remittances, migrants declined, citing the corruption in previous partnerships between citizens of Corporeo and the municipal government. Beto was pleased the relationship to some paisanos had changed during his administration and was hopeful the next administration would continue the efforts he started.

Citizens of Corporeo reelected the PAN in the July 2006 elections. Ahuacatl residents overwhelmingly supported Bricio, the PAN candidate. Bricio was the director of social development in Beto's administration and several Ahuacatl residents became acquainted with him working on the church pavement project. Bricio campaigned on a public works platform. Building on the relationship formed with the paisanos during Beto's last year in office, Bricio made the $3 \mathrm{x} 1$ Program a key component of his development plan. He explained: 
The best mayors, the most successful mayors who do projects for the people of their towns, are not necessarily the ones with the most revenue. There are many mayors who have resources but they can be lazy or corrupt. But municipalities that want to improve the lives of citizens without resources have to go and find the resources and manage them well (gestion) to do things that help make the people happy. Part of the job is finding program after program that your municipality qualifies for and get more resources. The 3x1 Program is a program like that.

Working with Ahuacatl residents and paisanos on projects through the $3 \mathrm{x} 1$ Program required concessions on the part of the municipal government. The church renovation project was not a priority for Beto and his team since they prioritized the provision of basic services. But they identified the need to work with the migrants and residents and support some of their wishes so they could gain their trust and continue working together on drainage and potable water projects, which the public officials cited as the most pressing needs of Ahuacatl. As a result of this collaborative approach Beto and later Bricio completed several projects with Club Ahuacatl including the church pavement and bathroom project, street pavement and sidewalk projects, and new street lamps in the town.

\section{MIGRANT SOCIAL EMBEDDEDNESS AND \\ COMMUNITY INCLUSION}

Juan was a well-known resident of Ahuacatl even though he had lived in the U.S. for many years. He had a strong bonding social network in Ahuacatl and continued to practice cultural repertoires of community membership when he was in town. Both parents, several siblings, and friends from elementary school with whom he had remained close after his departure all lived in Ahuacatl. Once Juan landed his job at the day school, his good pay and job security allowed him to build a house for his family, Yesenia and her two sons, just as he had dreamed. He built the house across the street from his childhood home where his parents still lived and where several siblings lived nearby with their own growing families. He bought a new truck that stayed in the garage to use during his visits. He purchased land for a brother outside of town. He fixed up his parent's house. And when he came, he brought small tokens of affection to friends from elementary school and family members-Chargers baseball hats (the San Diego NFL team at the time), materials to fix up their houses, and trinkets such as little bracelets and necklaces for his nieces. He liked to take long walks or ride on his horse when he was in town to say hello to people. When I accompanied him as he went through town, store owners came outside to greet him. Despite his absence and the new luxuries social mobility offered Juan and his family, residents did not seem to begrudge his success because he shared it with them. Juan was seen as a man of Ahuacatl, even though he no longer lived there year-round. He was still a part of his hometown community and the town's favorable opinion of Juan was extended to the paisano club. This was 
why El Guaje and local leaders wanted Juan to run the club. They believed he would represent the people of Ahuacatl because he was still one of them.

Juan's popularity was also aided by the admiration citizens had for his older brother, Caesar. When I accompanied him into Corporeo, acquaintances who he did not know well, but who knew his brother, would yell "Brother Zamora! Órale!" Caesar lived in Celaya and he was a rodeo and party promoter throughout the region. Everyone around town knew about Caesar's parties and traveled several kilometers to attend them, especially when he booked popular banda groups. In 2007, after the migrant club had completed a few projects successfully and Juan had become more confident in his fundraising abilities, he started to throw rodeos in Ahuacatl with Caesar to fundraise for the town. When the brothers brought the popular regional social events to Ahuacatl, many residents credited the Zamora family for bringing positive attention to the small town. The rodeo gave residents something to be excited about and everyone wanted to chip in to make the event a success. The rodeo also further expanded Juan's social ties throughout Ahuacatl and to other localities in Corporeo.

Juan had both bonding and bridging ties in Ahuacatl. His bonding social ties included kin (siblings, nieces and nephews, and their friends) and fictive kin relationships (godchildren and godparents), and he had bridging ties to stakeholders in the town, such as church leaders, El Guaje and Guaje's elite friends (the dentist, doctor, and "el profesor," a retired schoolteacher who catalogued the colonial history of Corporeo), and schoolmates who were small shop owners. Furthermore, residents who were active in the church group and worked with the club also drew on their social networks to support the club's public works efforts. The paisanos' social ties and embeddedness in the town were paramount to their success scaling up community involvement in public goods provision with municipal authorities, but it became even more important when the economic crisis in the U.S. decreased the club's capacity to coproduce public works projects through the 3X1 Program.

\section{ECONOMIC RECESSION AND THE CHALLENGE TO HTA CLUB CAPACITY}

The success of $3 \times 1$ projects in Ahuacatl invigorated local residents, who had many $3 \mathrm{X} 1$ project ideas they wanted to see implemented in the town. In 2008, teachers from the local kindergarten asked for a meeting with El Guaje and Juan during his visit home during the Thanksgiving holiday. With the encouragement of the teachers and parents of the jardin de niños (kindergarten), the school group asked the migrants to help them with a problem in their school: excessive overcrowding. At the time, one teacher supervised 50 students. El Guaje suggested they build a new classroom addition to the school and hire one of the teachers who was laid off from a nearby school that recently closed. Juan and El Guaje thought it was a wonderful idea. El Guaje organized a meeting with political officials to propose the 3X1 
project and Juan agreed to bring the idea back to the paisanos in the club. Shortly after, the mayor agreed and worked with his administration to submit technical plans and approval through the 3xi Program.

The mesa directiva (parent-teacher association) of the school met with Corporeo's director of social development and El Guaje while Juan, Ramon, and other members of Club Ahuacatl fundraised back in the U.S. During the meeting, parents expressed concern that construction during the school year would be dangerous for the children, but they did not want to wait until July when school ended because of the elections. Everyone in the meeting worried that the elections would stall the project. Residents' concern was that if an opposition party took power there were no assurances that the new administration would complete the $3 \times 1$ school project. The residents had good reason to be concerned about party turnover because the PAN candidate running for the mayorship was very unpopular with locals. Residents thought the PRI candidate, Carlos, was going to win even though they had developed strong partisan attachments for Beto and Bricio, Panista mayors of Corporeo, whom voters in Ahuacatl credited for the improvement in public goods provision in their town.

Carlos served as mayor of Corporeo in the early 1990 and he opened the first Corona beer company bottling plant in the region, which brought many jobs to the people of Corporeo and the region. Paisanos and residents alike wanted to work with whichever party was elected, but they had concerns that Carlos's administration might not honor projects started during the PAN incumbent's last year in office. Bricio reassured everyone involved that they would start and finish the classroom project before the new administration took office. This was also a strategic decision by Bricio since he wanted to prevent the PRI administration from taking credit for his projects in order to sway unsuspecting voters during the election campaign season.

Martin, Ramon, Juan, and other paisanos tried to fundraise for the school expansion project as they had done for previous $3 \times 1$ projects. But in late 2008 and 2009 the U.S. housing crisis was in full swing. The economic crisis severely dampened the club's capacity to raise funds for their hometown. Martin, who worked in the construction industry, was worried he would lose his job and have to return to Mexico. This was the same predicament for many paisanos from Corporeo who also worked in housing construction. Club Ahuacatl was able to raise some contributions, but not the full 25 percent stipulated by the 3x1 Program. Embarrassed, Juan recalled how awful he felt when he returned to Ahuacatl and told the mesa directiva of the school that the paisanos were unable to raise project funds for the schoolhouse.

Members of the school group were disappointed. But they also understood too well the migrants' difficulties since many of the children in the school had parents in the U.S. who feared the loss of their jobs and ability to send home remittances. Parents offered to fundraise to help cover the remaining cost in order to continue 
the project. They held potluck dinners and took donations from willing families, whatever they could spare. Juan was adamant that the club never pressure the residents for money because he knew many of the families had a member in the U.S. and that times were tough. Juan was very vocal about this at the meeting I attended. Together with Juan's brother, the mesa directiva, El Guaje, and the church association, citizen groups offered to pitch in.

When Juan told Caesar about the decline in the club's capacity to fundraise for the school project, Caesar offered to throw the next jaripeo in Ahuacatl. Ahuacatl had never hosted a rodeo in their own town and everyone buzzed with excitement. Residents volunteered and sold tickets to the event all over Corporeo and nearby municipalities. Other residents posted fliers for the event in other municipalities to attract people from all over the region. The church group held a raffle for a fat calf they called "Miguel," and made food to sell at the event. The rodeo was a huge success and raised more than enough to cover the 25 percent migrant contribution to the school project. As a result of the collective mobilization of residents all across town during a decline in the club's capacity to raise $3 \times 1$ funds, construction broke ground in June and the entire project wrapped up in August. The ribboncutting ceremony for the schoolhouse was an emotional event for the residents of Ahuacatl who were proud of their accomplishments, and for Juan, who was unsure if his club would be able to do any more projects with paisanos' investment as they increasingly struggled to make ends meet in the U.S.

While the school classroom was being built in July, Carlos won the mayorship. Much to residents' surprise, despite PRI party turnover in municipal government, Carlos immediately set up formal meetings with Club Ahuacatl and community residents to plan $3 \times 1$ projects during his administration. At the meeting, Juan informed the mayor that Club Ahuacatl was unable to collect the remittances of paisanos in the U.S. as they had done before the economic crisis and would likely have to disband the club. By late 2009 and well into 2010, the economic crisis depressed the paisanos' ability to raise funds for coproduction projects in Ahuacatl.

Hearing of the migrant club's difficulty raising funds in the U.S., Chumo, the dentist who had been involved in earlier $3 \times 1$ projects, offered to organize a public works committee for the town. The comite de obras was a group of five Ahuacatl residents who wanted to keep up the momentum for public works projects even though the paisanos could no longer be actively involved in the partnership. Chumo explained that members of the comite "all share the same vision for the town ... we can help the paisanos with the 25 percent and we can still do projects through the 3x1 Program." With Juan, Martin, and Ramon's blessing, the public works committee completely took over project selection, planning, and implementation efforts with the municipal government. The only involvement that Club Ahuacatl had in the coproduction process was to propose the projects to the COVAM for 3x1 Program approval so that the municipality could still quality for state and federal matching funds. 
Members of the public works committee did not believe that the municipal government would still want to engage in coproduction projects if they could no longer participate in the $3 \times 1$ Program. Enrique, a member of the public works committee, reflected on how town life has changed since Club Ahuacatl began supporting projects:

The two biggest problems in Ahuacatl are drinking water and drainage. We could not do these kinds of projects by ourselves ... Listen, before people wanted to be involved, but having the migrant club has definitely increased residents' participation in the town ... It is easier to get people in the town involved when there are incentives like different state or municipal programs like 3xi. When the people know they don't have to do the whole [project] by themselves and that they have the support from government officials, they are more likely to do something. Since $3 \times 1$, there are more requests for little projects. I think this is because people were not sure if the projects would actually happen, but now that they see the patio project done, and the school, and the roads, they have more confidence and will talk to our committee.

Before Club Ahuacatl, residents were active in the social life of the town, but the migrant club helped scale up participation in public works projects. This participatory engagement in coordination with public officials created new terrain for democratic decision-making outside the electoral process.

While El Guaje and prominent members of Ahuacatl were the driving forces behind the formation of the hometown association, after several projects were completed in the locality, more residents became actively involved in the 3x1 coproduction process. Juan's social embeddedness in Ahuacatl meant that his leadership in the migrant club garnered support for coproduction projects that directly involved the municipal government. Members of the town knew Juan, who was perceived as a member of the Ahuacatl community, even though he had lived abroad for more than 20 years. Since paisanos had maintained solidaristic ties with residents of the hometown beyond their immediate social circles, a more heterogeneous group of citizens were involved in the coproduction process. And as community inclusion increased with the successful completion of $3 \times 1$ projects and more residents took ownership over public projects, they had more routinized interactions with elected public officials including Beto, Bricio, Carlos, and other political officials who were part of the PAN and PRI municipal administrations.

The fierce electoral competition in Corporeo created political incentives for the municipal administration to become engaged in the coproduction process with migrants, as in the case of El Cerrito. Beto and Bricio both pursued campaign platforms based on the provision of public works. The mayors, including the PRI administration from 2009-12, viewed the 3x1 Program as an opportunity to expand social spending throughout Corporeo. The active involvement of community residents presented municipal officials with an opportunity to work with their constituents and develop relationships with stakeholders in the community. The process of coproducing public works helped to repair some of the mistrust 
in local government. As Gema, a local Ahuacuatl resident, told me, "It's better now, but it is always a good idea to keep a healthy distance when it comes to the Mexican government."

The combination of high community inclusion and government engagement organized synergetic coproduction in Ahuacatl. During the U.S. economic downturn, residents of Ahuacatl scaled up their participation to help the migrants overcome financial constraints to continue working on projects through the $3 \mathrm{X} 1$ Program. This escalation in civic participation had additional positive spillovers for democratic participation. Residents reported that their interactions with municipal officials of both parties showed them that the government responded to their needs when they made their voices heard, even if they never fully trusted politicians. Over the course of the three mayoral administrations in which Club Ahuacatl and community residents engaged in coproduction (2004-12), government spending on public works was 3 percent higher, on average, compared to the previous period (2002-04). All of the localities with an active migrant club, including Ahuacatl, received a higher distribution of public spending than they did before. Although the PAN administration did not win the 2009 election, residents continued to work effectively with Carlos's PRI administration, completing an additional four coproduction projects in Ahuacatl without collective remittances from the migrant club. As a result of the synergetic partnership forged between citizens, migrants, and political officials, 10 coproduction projects were successfully completed in Ahuacatl in Carlo's three years as mayor during the U.S. economic crisis. Coproduction created a new institutional venue through which citizens could participate more in social and political affairs of their community.

As of 2013, Club Ahuacatl continued to support the provision of public goods in Ahuacatl, but no longer with collective remittances. Juan used his status as a paisano and proposed projects through the 3x1 Program for cofinancing from the state, federal, and municipal governments, but was no more involved than that. Instead of migrants' remittance contributions, the public works committee of Ahuacatl contributed the 25 percent share for projects. Club Ahuacatl never recovered their capacity to fundraise and keep paisanos interested in coproduction activities through the economic crisis. In 2010, Martin and Ramon stopped participating in the club altogether and said it took up too much time and attention. The club became inactive in 2011 after seven years of successful coproduction in Ahuacatl, but 3X1 coproduction projects continued without them. Juan still visited several times a year and threw parties with his brother. He continued to enjoy everyday life in his hometown with friends, new and old, and his family and the people of Ahuacatl.

\section{SUMMARY}

The two cases in this chapter represent examples of intermediary organizational forms of transnational coproduction that differed in their levels of community 
inclusion and government engagement. But in both cases additional factors beyond electoral incentives, local-state capacity, and migrant social embeddedness impacted levels of community inclusion and government engagement.

In the PRI stronghold of Santa Catarina, local residents were uninterested in direct involvement in coproduction so long as it involved public officials who many suspected of being corrupt or in cahoots with criminal organizations. Moreover, local political officials were all but secured electoral victory by the cacique in town and public goods provision was not part of the electoral calculus to turn out voters in municipal elections. In Ahuacatl, migrants, especially the HTA leader who was the most visible ambassador of the migrant club in the hometown, were socially embedded, possessing both bonding and bridging ties throughout the community despite having lived in the U.S. for decades. Moreover, local government was eager to work with paisanos on projects, in Ahuacatl especially, as they thought they could benefit from the amplification of resources for public spending through the 3x1 Program in an electorally competitive locality that was known to support both PRI and PAN mayoral candidates. But when club capacity was severely contracted by the U.S. economic recession, because paisanos had helped forge network ties between community leaders in Ahuacatl and the local government through the coproduction process, $3 \times 1$ projects were able to continue with the increase in residents' ownership and leadership in local public goods provision.

In the synergetic partnership in Ahuacatl in which both inclusion and engagement were high, residents became active participants in the coproduction process with a fully engaged local government. Political officials in Corporeo supplied matching funds, proposed projects, provided technical planning and support, hired labor, and coordinated materials to the coproduction process. Because they were keen on receiving matching funds from the state and federal governments to provide public goods in a more politically competitive part of town, public officials were open to negotiation with the migrant club and resident actors. When the U.S. recession challenged Club Ahuacatl's capacity to collect resources for coproduction projects and keep club members involved in club activities on the U.S. side of the border, residents increased their involvement in public goods provision to supplement the club's investment. To do so, community members volunteered to form a public works committee, a new civic association in town, and work with the delegate and municipal officials to continue coproduction projects without the involvement of the migrant club, but still through the 3x1 Program. In sum, synergy, despite a decline in HTA club capacity, was associated with an increase in local civic and political participatory engagement.

By contrast, in Santa Catarina migrants were not as socially embedded in the town as paisano club leaders from Ahuacatl. The paisanos from Santa Catarina, who reluctantly formed a club at the request of the local priest and excited members of the paisano network in Chicago, had weak bonding and bridging social networks. High rates of out-migration coupled with over 20 years away from 
the hometown and few visits during those years eroded social ties to local residents. Most of the paisanos' family, close friends, schoolmates, and neighborhood acquaintances had also emigrated and either joined the paisanos in the Chicago metro area or emigrated to other parts of the U.S., namely Texas and California. In other words, paisanos bonding networks relocated with them to the U.S. and paisanos only had a few social connections to people who remained behind.

Bridging ties were also in short supply because there were few community leaders in the hometown aside from the local priest. The popular local pastor introduced migrant club leaders to parishioners when they were in town for two different religious festivals, but locals did not want to be involved and club members did not actively recruit them into project planning. Additionally, residents' mistrust of local political officials also discouraged their involvement when they learned that participation in the $3 \mathrm{x}$ Program required municipal government participation. And concerns about public security connected to the rise of criminal organizations and drug trafficking in the region further hampered local residents' interest in becoming involved in public affairs, which could potentially draw attention to the presence of remittance resources flowing into town. Relatedly, residents' concerns about the mayor's connections to nefarious activities further turned off community involvement in the transnational partnership.

In both cases in this chapter, factors beyond migrant social embeddedness and political bureaucratic capacity and competitiveness affected levels of community inclusion and government engagement. Drug violence and the U.S. economic recession had an independent effect on the organization of transnational partnerships and also through their effect on community inclusion and government engagement. Additional factors specific to the hometown setting needed to be accounted for to more fully explain variation in the organization of transnational partnerships.

In the next chapter, I present the final two cases of transnational partnership between migrant clubs and public agencies in the Mexican sending state. The cases of El Mirador and Atitlan are different than other cases in that both partnerships represent different localities that are in the same municipality, whereas the previous four cases were each in different municipalities. The benefit of a within-municipal case comparison is that it allows me to hold constant local bureaucratic capacity of the state and trace how migrant social embeddedness and electoral considerations in different localities shaped community inclusion and government engagement to different organizational forms of partnership (corporatist and synergetic) and to diverse political outcomes and effects on state-society relations. 